\title{
A VIRUSLIKE DISEASE OF SORGHUM IN PUERTO RICO
}

In July 1954, two stools of Merker grass, Pennisetum purpureum var. Merkeri collected at the Lajas substation and presenting symptoms resembling a viruslike disease were brought to the attention of the writer by Efrain Boneta of the staff of this Station.

The most conspicuous symptom of the disease was a creamy-yellow freckling and striping of the leaves, especially the top ones. The stripings began first to appear at the base of the still unfurled topmost leaf, and extended upward as parallel contiguous yellowish streaks. Reddish specks apparently due to the necrotization of the chlorotic tissue were to be seen in most cases, especially in the region close to the midrib. In severe cases many of the top leaves did not unfurl properly but remained close and twisted. The whole plant was badly stunted and the shortened internodes imparted a bunchy-top aspect to it.

Cultures made from affected tissues yielded only a yellowish, unidentified bacterium and two fungi belonging to the genus Curvularia and Colletotrichum. So far none of the isolated organisms has proved to be pathogenic when inoculated on healthy Merker plants. Attempts to transmit the disease to healthy Merker, sorghum, and sugarcane plants by juice inoculation with the aid of carborundum, or by pin-pricking, using infectious juice, have so far been unsuccessful.

The possibility that the disease might be due to $2-4 \mathrm{D}$ or other herbicide injury was discarded when an inquiry made at the time failed to disclose

any applications either in the plantation or its vicinity. Also it is difficult to reconcile with the above-mentioned view the fact that only two plants among many were affected. Nutritional disturbances were also ruled out when the disease condition persisted after transplanting the stools to a rich, well-manured soil.

The disease condition is transmitted serially through cuttings and is accompanied by a progressive decline in the vigor of the stools. Immersion of the affected cuttings in water at $52^{\circ} \mathrm{C}$. for 20 minutes resulted in the production of healthy plants.

We have been unable to find in the available literature reports of a disease of $P$. purpureum var. Merkeri which corresponds to the one under study. However, Cheriam and Kylasam" described two diseases, "freckled yellow" and "stripe" of sorghum in India, which have many points of similarity with the disease reported in this paper.

\section{J. Adsuar}

Department of Plant Pathology

1 Cherian, M. C., and Kylasam, M. S., Preliminary studies on the "freckled yellow" and "stripe" diseases of Cholam, Proc. Assn. Econ. Biol., Coimbatore, 1936, 4 57-63, 1937. 